\title{
Erratum to: Long-term shifts in the cyclicity of outbreaks of a forest-defoliating insect
}

\author{
Andrew J. Allstadt • Kyle J. Haynes • \\ Andrew M. Liebhold · Derek M. Johnson
}

Published online: 6 January 2013

(c) Springer-Verlag Berlin Heidelberg 2013

\section{Erratum to: Oecologia}

DOI 10.1007/s00442-012-2474-x

Unfortunately, the original version of the article has a typographical error in Eq. 5 which is corrected as given below:

$N_{\mathrm{A}}^{\prime}=d\left(\frac{c P_{t}}{\ln \lambda}-1\right)$.

The online version of the original article can be found under doi:10.1007/s00442-012-2474-x.

A. J. Allstadt $(\bowtie) \cdot$ K. J. Haynes

The Blandy Experimental Farm, University of Virginia, 400 Blandy Farm Lane, Boyce, VA 22620, USA

e-mail: andrew.allstadt@virginia.edu

\section{A. M. Liebhold}

USDA Forest Service, Northern Research Station,

180 Canfield Street, Morgantown, WV 26505, USA

D. M. Johnson

Department of Biology, Virginia Commonwealth University,

Richmond, VA 23284, USA 